Available online at : http://journal.unj.ac.id/unj/index.php/gjik

Gladi : Jurnal Ilmu Keolahragaan 09 (02) 2018, 96 - 107

Permalink/DOI: https://doi.org/10.21009/GJIK.092.03

\title{
PENGARUH METODE LATIHAN DAN KOORDINASI MATA TANGAN TERHADAP KETERAMPILAN MEMUKUL BOLA SOFTBALL
}

\author{
Arief Rahman $^{1 *}$, Yusmawati $^{2}$ \\ Pendidikan Olahraga, Pascasarjana Universitas Negeri Jakarta \\ Jl. Rawamangun Muka, Jakarta Timur, Indonesia 13220 Universitas Negeri Jakarta ${ }^{1}$ \\ *Corresponding Author. Email: Ariefrahman0705@gmail.com
}

\begin{abstract}
Abstrak, Penelitian ini bertujuan untuk mengetahui pengaruh dari variabel- variabel bebas yaitu metode latihan dan koordinasi mata tangan terhadap variabel terikat yaitu keterampilan memukul bola softball. Disamping itu juga untuk mengetahui ada tidaknya interaksi antara kedua variabel tersebut yang mempengaruhi peningkatan keterampilan memukul bola softball. Metode yang digunakan adalah Metode penelitian experimen dengan analisis by level 2x2 melalui random sampling dengan jumlah sampel 36 orang. Hasil penelitian menyimpulkan hal-hal berikut: 1) Terdapat perbedaan antara kelompok atlet yang menggunakan metode latihan batting tee dan kelompok atlet yang menggunakan metode latihan hitting a soft toss tehadap keterampilan memukul bola softball, 2) Terdapat interaksi antara metode latihan dan koordinasi mata tangan terhadap keterampilan memukul bola softball, 3) Terdapat perbedaan keterampilan memukul bola softball antara kelompok atlet yang menggunakan metode latihan batting tee dan kelompok atlet yang menggunakan metode latihan hitting a soft toss pada kelompok atlet yang memiliki koordinasi mata tangan tinggi, 4) Terdapat perbedaan keterampilan memukul bola softball antara kelompok atlet yang menggunakan metode latihan batting tee dan kelompok atlet yang menggunakan metode latihan hitting a soft toss pada kelompok atlet yang memiliki koordinasi matatangan

rendah.
\end{abstract}

\section{Kata Kunci : Batting tee, Hitting a Soft Toss, Koordinasi Mata Tangan, Memukul}

\begin{abstract}
This study aims to determine the effect of independent variables, namely the training method and hand-eye coordination on the dependent variable, namely the skill of hitting softball balls. Besides that, it is also to find out whether there are interactions between the two variables that affect the increase in the skill of hitting softball balls. The method used is experimental research method with $2 \times 2$ by level analysis through random sampling with a sample of 36 people. The results of the study conclude the following points: 1) There is a difference between groups of athletes who use the batting tee training method and the group of athletes who use the hitting a soft toss training method to hit softball skills, 2) There is interaction between training methods and eye hand coordination on softball hitting skills, 3) There is a difference in softball hitting skills between groups of athletes who use the batting tee training method and athletes who use the soft toss hitting a training method in the athletes who have high hand eye coordination, 4) There are differences in softball hitting skills between groups of athletes who use the batting tee training method and athletes who use the soft toss hitting a training method in groups of athletes who have low hand eye coordination.
\end{abstract}

Keywords: Batting tee, Hitting a Soft Toss, Hand Eye Coordination, Hitting 


\section{PENDAHULUAN}

Olahraga softball pada saat ini cukup populer di Indonesia, hal ini bisa dilihat bukan hanya di kota-kota besar saja tetapi di daerah pun sudah memajukan cabang olahraga ini. Dengan adanya berbagai event kejuaraan nasional dan internasional bahkan pelajar dan umum menjadikan cabang olahraga ini cukup populer. Pada dasarnya berbagai teknik dasar yang harus di kuasai oleh seorang pemain dalam permainan softball menurut Parno dalam bukunya Olahraga Pilihan yaitu pitching, throwing, catching, batting, sliding, dan base running (Fahrul, 2016).Olahraga softball mempunyai karakteristik masing-masing, ciri dari permainan softball dapat dilihat dari sifat permainan, teknik gerakan dan peraturan permainannya. Softball adalah permainan yang memerlukan kecepatan dan ketepatan, artinya permainan ini memerlukan kecepatan dalam berlari, kecepatan dan ketepatan dalam memukul dan melempar bola. Biomekanika dapat diartikan sebagai sebuah kajian yang menggunakan konsep mekanika dan mesin untuk mengungkapkan gerak manusia secara efisien (Nordin, Margareta dan Frankel, 2012).

Olahraga softball adalah permainan yang dimainkan oleh dua regu, permainan dimainkan oleh 9 orang yang membutuhkan kerja sama (Luby Tsani Ahwadi, yunyun Yudiana, Nurlan Kusmaedi, 2016).
Lamanya permainan softball ditentukan dengan inning, masing-masing regu akan mendapat giliran tujuh kali menjadi regu penyerang dan tujuh kali menjadi regu penjaga. Regu penyerang menjadi regu penjaga apabila telah terjadi tiga mati, dengan demikian regu penjaga mendapat giliran untuk menjadi regu penyerang, begitu juga sebaliknya regu penjaga menjadi regu penyerang apabila telah mematikan tiga orang penyerang maka regu penjaga menjadi regu penyerang. Namun, pada dasarnya regu penyerang berusaha semaksimal mungkin untuk dapat memukul maupun melakukan strategi sehingga selamat sampai base satu, base dua, base tiga bahkan mencapai home plate untuk menghasilkan runner sebanyak mungkin. Sedangkan regu defensive berusaha untuk mempersulit dan mematikan batter dalam memukul bola melalui pitchernya, serta berusaha mematikan pelari dalam usahanya untuk mencapai base yang dituju. Hal ini merupakan salah satu ciri khas dari permainan softball. Jadi disetiap pemain dituntut untuk menguasai teknikteknik dasar, taktik bertahan (defensive) dan taktik menyerang (offensive).

Diantara beberapa teknik dalam cabang olahraga softball, keterampilan memukul termasuk salah satu keterampilan yang penting yang harus dikuasai oleh seorang pemain softball, Memukul adalah salah satu teknik yang sangat penting dalam 
olahraga ini. Ketika tidak mempunyai keterampilan memukul maka pemain tidak akan mendapatkan poin (Taufik Rihatno, 2014) adapun didalam pelaksanaannya teknik memukul terdapat beberapa variasi yaitu terdapat berbagai macam jenis memukul hit, bunt, hit and run dan lainnya. Tergantung situasi yang terjadi saat itu. Berbagai macam jenis hit digunakan sesuai strategi yang akan dibuat tim penyerang. Dalam penelitian ini peneliti akan membahas tentang satu jenis pukulan yaitu hit dimana dalam jenis pukulan ini atlet dituntut untuk ketepatan dan kordinasi mata tangan tinggi dalam melakukan pukulan dari rangkaian gerak awal sampai perkenaan kepada bola dan menghasilkan pukulan yang baik.

Berdasarkan hasil observasi lapangan dan wawancara kepada pelatih softball di Club Softball UNIMED kota Medan, dalam praktiknya tidak semua pemain mampu melakukan gerakan memukul dengan maksimal, apalagi bentuk latihan pukulan hit ditemukan adanya masalah dalam penguasaan keterampilan memukul. Karena dalam melakukan hit gerakan memukul harus baik dan benar. Salah satunya keterampilan memukul merupakan keterampilan yang sulit untuk dikuasai, Karena keterampilan memukul bola softball membutuhkan penguasaan gerak yang sistematis, pandangan mata harus melihat ketangan pitcher, posisi tangan memegang bat harus setinggi bahu, putaran pinggang saat memukul, kemudian posisi batter saat mau memukul, kaki dibuka selebar bahu. Kurangnya metode latihan para pemain saat melakukan pukulan hit membuat atlet merasa jenuh, hal itu dikarenakan masih belum efektif pengaturan gerak dan timing yang tepat saat memukul bola softball oleh para pemain, karena pengaturan timing sangat diperlukan saat memukul bola untuk hasil yang maksimal. Untuk itu diperlukannya metode latihan yang tepat dalam meningkatkan pukulan. Program latihan adalah seperangkat kegiatan dalam berlatih yang diatur sedemikian rupa sehingga dapat dilaksanakan oleh atlet, baik mengenai jumlah beban latihan maupun intensitas latihan. Latihan yang dilaksanakan dengan betul biasanya menuntut banyak waktu dan tenaga dari atlet, setiap atlet berupaya secara bertahap terus meningkatkan intensitas latihannya, untuk mengulang setiap bentuk latihan, dan untuk semakin meningkatkan prestasinya. Oleh karena itu tidak mengherankan kalau latihan demikian sering dapat menyebabkan rasa bosan. Untuk mencegah kemungkinan timbulnya kebosanan berlatih, pelatih harus kreatif dan pandai mencari dan menerapkan variasi dalam latihan, salah satunya menggunakan metode latihan. Latihan akan berjalan sesuai dengan tujuan apabila di program sesuai dengan pedoman latihan yang benar. Program latihan tersebut 
mencakup beberapa hal mengenai takaran latihan, frekuensi latihan, waktu latihan, dan prinsip-prinsip latihan lainnya. Program latihan ini disusun secara teratur, terukur dan di sesuaikan dengan tujuan latihan yang dibutuhkan.Karena salah satu aspek yang perlu diperhatikan adalah bagaimana seorang pemain softball harus bisa memukul bola dengan baik (Ridho,dkk, 2013).

Dalam olahraga prestasi keberhasilan atlet sering sekali menuntut keterampilan yang sempurna, karena orang yang terampil maka memiliki kemampuan untuk menghasilkan sesuatu dengan kualitas yang tinggi (cepat, cermat dan tepat). Diharapkan semua pemain berhasil memukul bola dengan tepat. Untuk meningkatkan keterampilan memukul bola yang baik banyak metode latihan yang digunakan dalam setiap latihan baik menggunakan batting tee, hitting a softtoss, pitching mesin dan yang lainnya." The main difference is that a batter uses both arms to swing the bat and holds on to the bat after striking the ball, rather than throwing the bat" (Rod Cross, 2011).

Dengan adanya beberapa keterampilan memukul tentunya memiliki cara tersendiri dalam melatihnya ada beberapa cara dalam melatih keterampilan memukul tersebut diantaranya adalah dengan menggunakan metode latihan batting tee, dimana metode latihan ini memiliki sifat statis karena bola diletakkan diatas batting tee yang sebelumnya sudah disesuaikan pada tinggi masing-masing batter. Pada saat memukul bola biasanya dihasilkan beberapa macam hasil pukulan yang pertama perkenaan bat tepat mengenai bola atau impact, yang kedua slice atau memotong yang biasanya bat hanya mengenai sebagian dari bola, dan yang terakhir adalah swing kosong atau bat tidak mengenai bola sama sekali. James Tangkudung mendefinisikan tentang metode latihan keseluruhan yaitu sebagai berikut: "Metode latihan keseluruhan merupakan sebuah pengembangan latihan secara menyeluruh dikondisikan dengan materi kegiatan dan tujuan serta kekhususan dari tugas gerak serta berdasar pada prinsip latihan yang disampaikan"(James Tangkudung, Wahyuningtyas Puspitorini, 2012)

Penelitian ini peneliti menggunakan dua metode yang berbeda dengan karakteristik yang sama pertama adalah hitting a soft toss yaitu bola yang dilempar oleh teman, sebelum melempar temannya sudah diskusi dengan zona straight masingmasing sampel, setelah itu sampel memulai untuk memukul. Batting tee adalah salah satu metode latihan untuk menambah keterampilan dalam memukul, dimana bola diletakkan diatas batting tee yang sebelumnya sudah diukur sesuai zona straight pemukul.

Batting tee and hitting a soft toss bisa digunakan untuk melatih pukulan pada atlet 
mengikuti olahraga softball. Mereka dilatih dengan metode batting tee terlebih dahulu sebelum akhirnya memukul dengan metode lainnya dan dilanjut dengan lemparan pitcher. Tujuannya tentu untuk melatih mekanika gerak memukul dan melatih keterampilan mereka dalam memukul bola dari tingkat kesulitan yang rendah hingga yang susah.keterampilan gerak adalah kemampuan untuk melakukan gerakan secara efisien serta perwujudan dari kualitas koordinasi dan control atas bagian-bagian tubuh yang terlibat dalam gerakan (Widiastuti, 2014).

Permainan softball khususnya teknik keterampilan memukul merupakan kegiatan dengan gerakan yang membutuhkan kordinasi khususnya kordinasi mata dan tangan pemain menjadi salah satu faktor pendukung dalam melakukan teknik keterampilan dasar softball tidak terkecuali teknik latihan batting tee and hitting a soft toss.The ability to learn a wide variety of new motor skills throughout life is one of the most essential capacities $p$ ossessed by humans(Edward William H, 2011).

Berdasarkan latar belakang tersebut peneliti perlu melakukan penelitian tentang pengaruh metode latihan (batting tee and hitting a soft toss) dan kordinasi mata tangan terhadap kemampuan memukul bola softball di Club Softball UNIMED kota Medan. Penelitian ini diharapkan dapat digunakan baik secara teori maupun praktik. Secara teori penelitian ini mampu memberi kontribusi dalam penggunaan metode latihan (batting tee or hitting a soft toss) sebagai inovasi baru dalam meningkatkan keterampilan memukul bola softball. Kemudian secara praktik hasil penelitian ini dapat dijadikan sebagai acuan bagi peneliti selanjutnya yang tertarik untuk meneliti tentang keterampilan memukul bola softball dengan menggunakan metode latihan (batting tee and hitting a soft toss).

Penelitian ini bertujuan untuk mengetahui pengaruh dari variabel- variabel bebas yaitu metode latihan dan koordinasi mata tangan terhadap variabel terikat yaitu keterampilan memukul bola softball. Disamping itu juga untuk mengetahui ada tidaknya interaksi antara kedua variabel tersebut yang mempengaruhi peningkatan keterampilan memukul bola softball.

\section{METODE PENELITIAN}

Metode penelitian yang digunakan dalam penelitian ini adalah metode eksperimen. Metode ini digunakan atas dasar pertimbangan bahwa sifat penelitian eksperimental yaitu mencobakan sesuatu untuk mengetahui pengaruh atau akibat dari suatu perlakuan atau treatment. Di samping itu penulis ingin mengetahui pengaruh variabel bebas terhadap variabel terikat yang diselidiki atau diamati mengenai metode eksperimen ini. 
Variabel yang terdapat dalam penelitian ini terdiri atas dua variabel bebas, yaitu metode latihan dan koordinasi mata tangan. Metode latihan merupakan variabel bebas aktif dan terbagi ke dalam dua klasifikasi, yaitu metode latihan Batting Tee dan metode latihan Hitting a Soft toss. Sedangkan koordinasi mata tangan termasuk ke dalam variabel bebas atribut dan dibagi menjadi dua klasifikasi, yaitu koordinasi mata-tangan tinggi dan koordinasi mata-tangan rendah.
Adapun variabel terikat dalam penelitian ini adalah keterampilan memukul bola Softball.

Desain penelitian merupakan suatu rancangan penelitian yang digunakan pada penelitian yang dilaksanakan. Penelitian ini menggunakan desain treatment by level $2 \mathrm{x} 2$. Adapun rancangan peneltiannya digambarkan dalam tabel berikut:

Tabel 1. Desain treatment by level 2 × 2

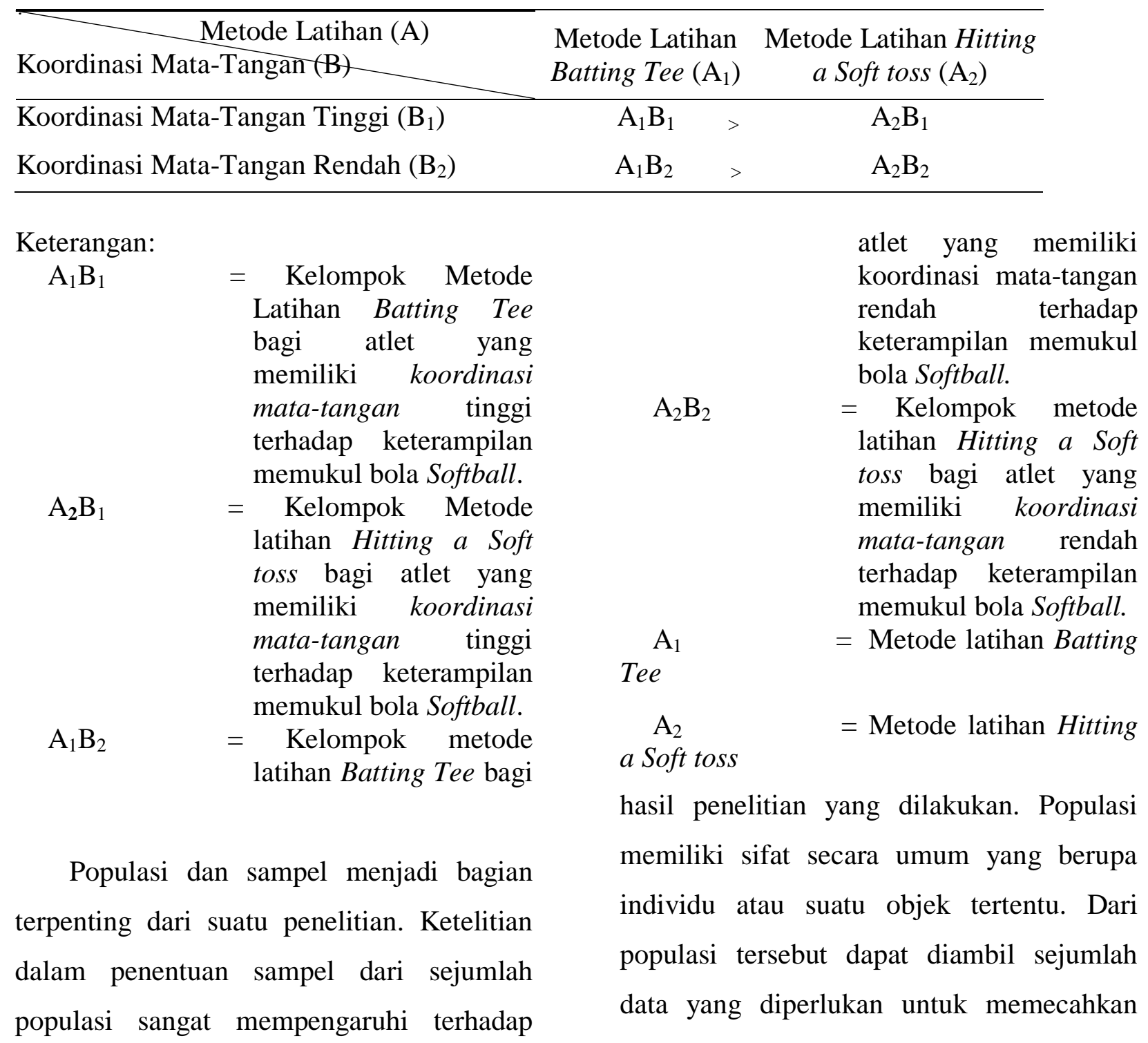


suatu masalah yang akan diteliti. "Populasi adalah wilayah generalisasi yang terdiri atas obyek atau subyek yang mempunyai kualitas dan karakteristik tertentu yang ditetapkan oleh peneliti untuk dipelajari dan kemudian ditarik kesimpulannya. Jadi populasi bukan hanya orang, tetapi juga obyek dan bendabenda alam yang lain".

Berdasarkan pada pendapat ahli di atas ditemukan kesimpulan tentang populasi bahwa bukan pada obyek atau subyek yang telah dipelajari, namun harus meliputi seluruh sifat atau karakteristik yang dimiliki oleh obyek atau subyek tersebut. Adapun yang menjadi populasi dalam penelitian ini adalah seluruh atlet club Softball Unimed kota Medan Tahun 2018 yang berjumlah 67 atlet.

Teknik penarikan sampel menggunakan randomized group design. Pendapat di atas memberi arti bahwa jumlah populasi terjangkau di random (diacak). Hasil dari random tersebut kemudian di tes koordinasi mata-tangannya. Setelah itu perolehan hasilnya dirangking.

Frank M. Verducci menjelaskan bahwa prosedur untuk mendapatkan kelompok koordinasi mata-tangan tinggi dan kelompok koordinasi mata-tangan rendah pada kedua metode tersebut. Pertama, 27\% dari skor total. Kedua, dari jumlah sampel yang dibutuhkan ambil dimulai dari urutan skor dari yang tertinggi dan urutan skor dari yang terendah, pertengahan skor antara yang tertinggi dan terendah dibuang atau dihilangkan.

Proses selanjutnya yaitu ambil $27 \%$ atas dari 67 orang berjumlah 36 sampel. Sehingga didapat urutan ke 1 s.d 18 masuk dalam kategori kelompok koordinasi matatangan tinggi dan urutan ke 50 s.d 67 masuk dalam kategori kelompok koordinasi matatangan rendah. Skor diantara koordinasi mata-tangan tinggi dan koordinasi matatangan rendah dihilangkan atau dibuang. Yaitu urutan ke 19 s.d 49 yang berjumlah 31 orang.

Terbentuk kelompok metode latihan dan kelompok koordinasi mata-tangan berjumlah 36 orang. Kemudian dari kelompok tersebut dibagi dengan $\mathrm{A}_{1} \mathrm{~B}_{1}$ (kelompok atlet yang memiliki koordinasi mata-tangan tinggi diberi perlakuan dengan metode latihan Batting Tee) sebanyak 9 orang. Kelompok $\mathrm{A}_{2} \mathrm{~B}_{1}$ (kelompok atlet yang memiliki koordinasi mata-tangan tinggi diberi perlakuan dengan metode latihan Hitting a Soft Toss) sebanyak 9 orang. $\mathrm{A}_{1} \mathrm{~B}_{2}$ (kelompok atlet yang memiliki koordinasi mata-tangan rendah diberi perlakuan dengan metode latihan Batting Tee) yang berjumlah 9 orang, dan $\mathrm{A}_{2} \mathrm{~B}_{2}$ (kelompok atlet yang memiliki koordinasi mata-tangan rendah diberi perlakuan dengan metode latihan Hitting a Soft Toss) yang berjumlah 9 orang. 


\section{Available online at : http://journal.unj.ac.id/unj/index.php/gjik Gladi : Jurnal Ilmu Keolahragaan 09 (02) 2018, 96 - 107 Permalink/DOI: https://doi.org/10.21009/GJIK.092.03}

\section{HASIL DAN PEMBAHASAN}

Data yang dianalisis berupa data skor keterampil an memukul bola softball dari 36 sampel atlet di Club Softball UNIMED kota Medan, yang terbagi menjadi 4 kelompok, yaitu: 1) kelompok atlet yang memiliki koordinasi mata-tangan tinggi dan diberikan perlakuan dengan metode latihan batting tee sebanyak 9 orang, 2) kelompok atlet yang memiliki koordinasi mata-tangan tinggi dan diberikan perlakuan dengan metode latihan hitting a soft toss sebanyak 9 orang, 3) kelompok atlet yang memiliki koordinasi mata-tangan rendah dan diberikan perlakuan dengan metode latihan batting tee yang berjumlah 9 orang, dan 4) kelompok atlet yang memiliki koordinasi mata-tangan rendah dan diberikan perlakuan dengan metode latihan hitting a soft toss yang berjumlah 9 orang.
Penelitian ini bertujuan untuk untuk menyelidiki, membandingkan dan mendeskripsikan secara komprehensif tentang perbedaan keterampilan memukul bola softball pada kelompok atlet yang memperoleh perlakuan metode latihan batting tee dan kelompok atlet yang memperoleh perlakuan metode latihan hitting a soft toss ditinjau dari koordinasi mata tangan (tinggi dan rendah). Penelitian kuasi eksperimen ini di dalamnya terdapat tiga variabel, yaitu skor hasil keterampilan memukul bola softball sebagai variabel terikat, dan metode latihan serta koordinasi mata-tangan sebagai variabel bebas.

Tabel 1 menunjukkan data skor akhir keterampilan memukul bola softball dari sampel yang diperoleh dari hasil penelitian.

Tabel 4 Data Skor Keterampilan Memukul Bola Softball

\begin{tabular}{ccccc}
\hline & \multicolumn{2}{c}{$\begin{array}{c}\text { Metode Latihan } \\
\text { Batting Tee }\end{array}$} & \multicolumn{2}{c}{$\begin{array}{c}\text { Metode Latihan } \\
\text { Hitting } \boldsymbol{a} \text { Soft Toss }\end{array}$} \\
\cline { 2 - 5 } No. & $\begin{array}{c}\text { Koordinasi Mata } \\
\text { Tangan }\end{array}$ & \multicolumn{2}{c}{$\begin{array}{c}\text { Koordinasi Mata } \\
\text { Tangan }\end{array}$} \\
& $\begin{array}{c}\text { Tinggi } \\
\text { Rendah }\end{array}$ & Tinggi & Rendah \\
1 & 84 & 74 & 79 & 70 \\
2 & 82 & 71 & 79 & 66 \\
3 & 83 & 76 & 76 & 70 \\
4 & 80 & 69 & 76 & 70 \\
5 & 84 & 68 & 74 & 67 \\
6 & 81 & 76 & 76 & 66 \\
7 & 80 & 70 & 71 & 67 \\
8 & 82 & 70 & 74 & 66
\end{tabular}




\begin{tabular}{lllll}
9 & 83 & 68 & 79 & 66 \\
\hline
\end{tabular}

Data skor pada aspek yang diukur, yaitu keterampilan memukul bola softball ditinjau dari metode latihan dan koordinasi mata-tangan terdapat pada Tabel 4.2 berikut ini:

Tabel 4 Statistik Deskriptif Skor Keterampilan Memukul Bola Softball

\begin{tabular}{ccccccc}
\hline Metode Latihan & $\begin{array}{c}\text { Koordinasi Mata } \\
\text { Tangan }\end{array}$ & $\mathbf{N}$ & $\boldsymbol{x}_{\text {maks }}$ & $\boldsymbol{x}_{\text {min }}$ & $\overline{\boldsymbol{x}}$ & $\boldsymbol{S}$ \\
\hline \multirow{3}{*}{ Batting Tee } & Tinggi & 9 & 84 & 80 & 82,11 & 1,537 \\
& Rendah & 9 & 76 & 68 & 71,33 & 3,202 \\
& Total & 18 & 84 & 68 & 76,72 & 6,057 \\
\multirow{3}{*}{ Hitting $\boldsymbol{a}$ Soft Toss } & Tinggi & 9 & 79 & 71 & 76,00 & 2,739 \\
& Rendah & 9 & 70 & 66 & 67,56 & 1,878 \\
& Total & 18 & 70 & 66 & 71,78 & 4,906 \\
\hline
\end{tabular}

Tabel 4 menunjukkan bahwa ratarata skor keterampilan memukul bola softball pada kelompok atlet dengan koordinasi mata tangan tinggi yang menggunakan metode latihan batting tee sebesar 82,11, sedangkan pada atlet dengan koordinasi mata tangan tinggi yang menggunakan metode latihan hitting a soft toss sebesar 76,00. Sedangkan rata-rata skor keterampilan memukul bola softball pada kelompok atlet dengan koordinasi mata tangan rendah yang menggunakan metode latihan batting tee sebesar 71,33, sedangkan pada atlet dengan koordinasi mata tangan rendah yang menggunakan metode latihan hitting a soft toss sebesar 67,56.

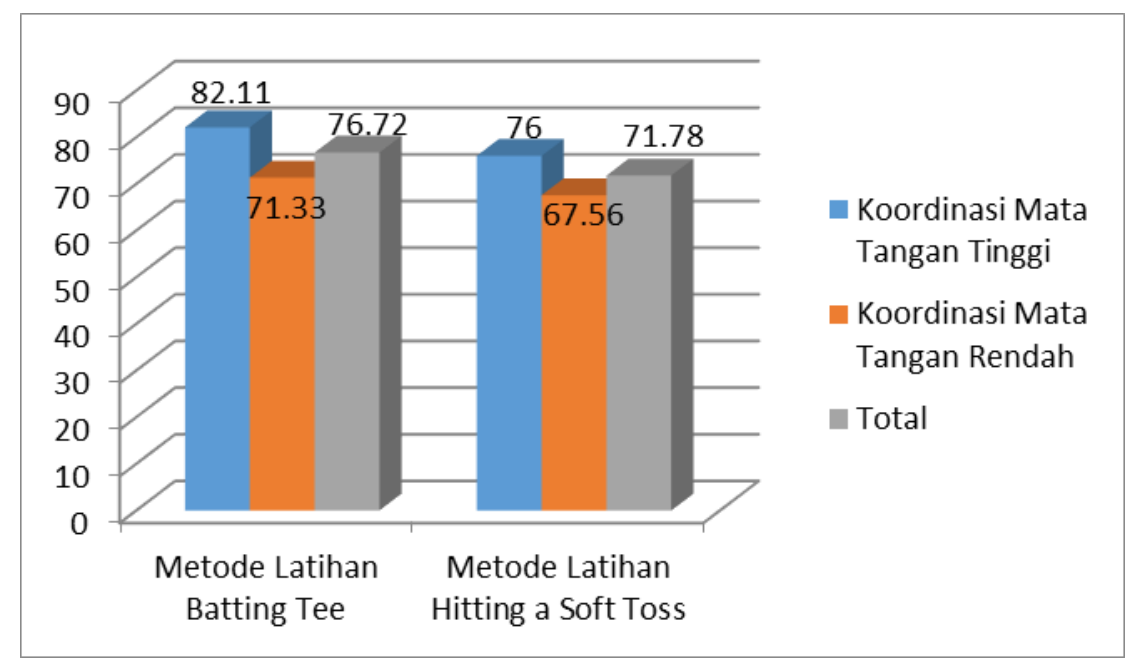

\section{Gambar 1 Perbandingan Rata-rata Skor Keterampilan Memukul Bola Softball}

Gambar diagram batang 1 kedua metode latihan ditinjau dari menunjukan perbandingan rata-rata skor koordinasi mata tangan. Gambaran keterampilan memukul bola softball pada perolehan skor keterampilan memukul bola 
softball pada ke-36 sampel penelitian dapat dilihat pada Gambar 4.2 dan Gambar 4.3. Gambar 4.2 merupakan diagram batang yang menunjukan perolehan skor keterampilan memukul bola softball pada kelompok yang mendapatkan perlakuan metode latihan batting tee ditinjau dari koordinasi mata tangan (tinggi dan rendah).

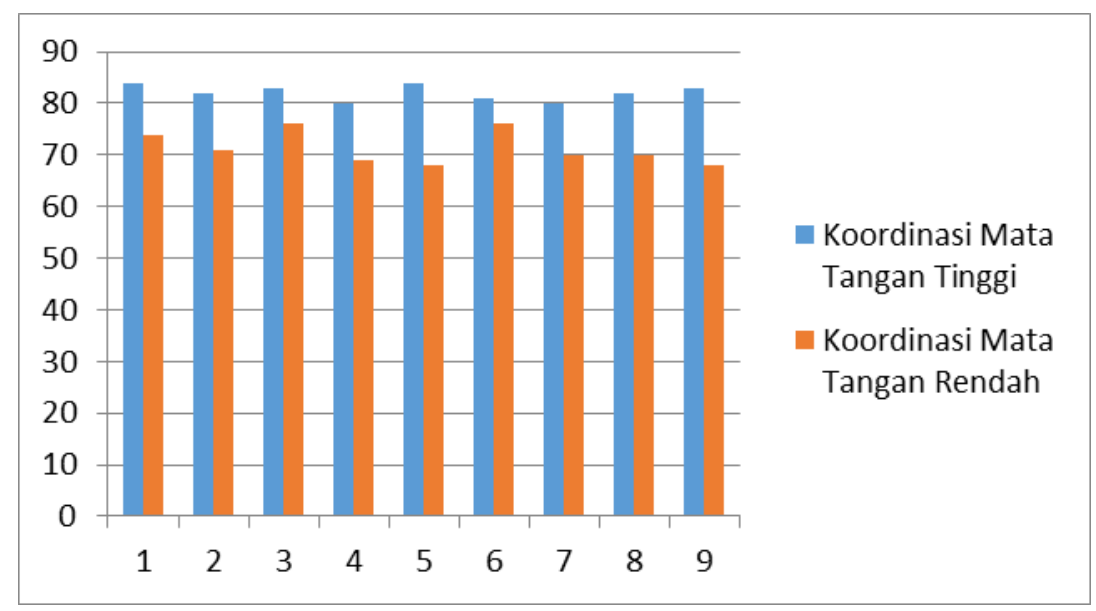

\section{Gambar 2 Perolehan Skor Keterampilan Memukul Bola Softball pada Kelompok yang Mendapatkan Perlakuan Metode Latihan Batting Tee}

Perolehan skor keterampilan hitting a soft toss ditinjau dari koordinasi memukul bola softball pada kelompok yang mata tangan (tinggi dan rendah) dapat mendapatkan perlakuan metode latihan dilihat pada Gambar 4.3 berikut:

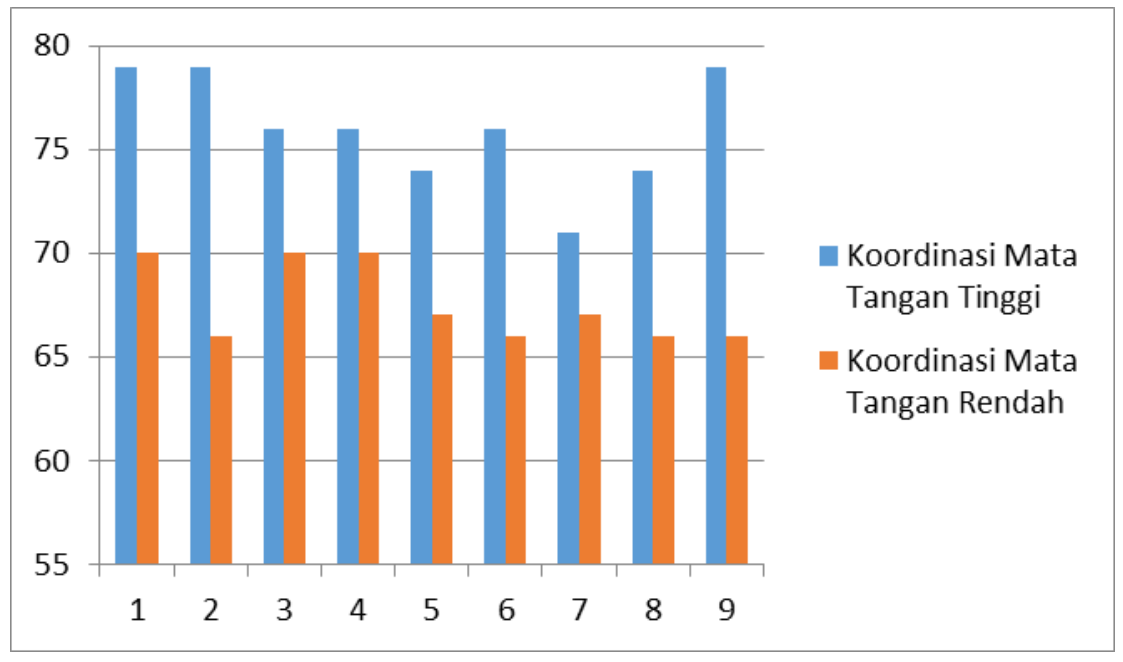

\section{Gambar 3 Perolehan Skor Keterampilan Memukul Bola Softball pada Kelompok yang Mendapatkan Perlakuan Metode Latihan Hitting a Soft Toss}

$\begin{array}{lll}\text { Keterampilan memukul bola softball } & \text { terdapat perbedaan keterampilan memukul } \\ \text { ditinjau dari metode latihan maupun } & \text { bola softball pada kelompok atlet yang } \\ \text { koordinasi mata tangan. Meskipun } & \text { menggunakan metode latihan batting tee dan } \\ \text { demikian, untuk menyimpulkan apakah } & \text { kelompok atlet yang menggunakan metode }\end{array}$


latihan hitting a soft toss ditinjau dari koordinasi mata tangan (tinggi dan rendah), perlu dilakukan uji hipotesis dengan menggunakan Anava Dua Jalur (Two Way Anova). Apabila hasil menunjukkan adanya pengaruh utama (main effect) antara variabel bebas terhadap variabel terikat dan adanya interaksi (simple effect) variabel bebas terhadap variabel terikat maka dilanjutkan dengan uji tuckey sebagai uji lanjut untuk menentukan kelompok mana yang memiliki keterampilan memukul bola softball yang lebih baik yang dilakukan pada taraf signifikansi $\alpha=0,05$.

Kesimpulan

Penerapan dipenelitian ini menggunakan metode eksperimen yang terdiri dari variabel terikat, yaitu hasil keterampilan memukul bola Softball sedangkan pada variabel bebasnya, yaitu metode latihan (batting tee dan hitting a soft toss) dan koordinasi mata-tangan (tinggi dan rendah). Berdasarkan dari data analisis yang diperoleh dan hasil uji hipotesis penelitian, maka mendapatkan suatu kesimpulan, yaitu:

1. Terdapat perbedaan antara kelompok atlet yang menggunakan metode latihan batting tee dan kelompok atlet yang menggunakan metode latihan hitting a soft toss terhadap keterampilan memukul bola softball.

2. Terdapat interaksi antara metode latihan dan koordinasi mata tangan terhadap keterampilan memukul bola softball.
3. Terdapat perbedaan keterampilan memukul bola softball antara kelompok atlet yang memperoleh perlakuan metode latihan batting tee dan kelompok atlet yang memperoleh perlakuan metode latihan hitting a soft toss pada kelompok atlet yang memiliki koordinasi mata tangan tinggi.

4. Terdapat perbedaan keterampilan memukul bola softball antara kelompok atlet yang memperoleh perlakuan metode latihan batting tee dan kelompok atlet yang memperoleh perlakuan metode latihan hitting a soft toss pada kelompok atlet yang memiliki koordinasi mata tangan rendah.

\section{DAFTAR PUSTAKA}

Edward, William H. "Motor Learning and Control: From Theory to Practice". Wadswort: Cengage Learning, 2011.

Fahrul, "Hubungan Antara Koordinasi Mata dan Tangan Terhadap Ketepatan Lemparan atas Softball Anggota UKM Baseball-Softball UNY", Jurnal Ilmu Keolahragaan UNY, Vol.1 No.2 Tahun 2016.

Gola, Mark. Winning Softball for Girls Second Edition, New York: Chelsea House, 2012.

Luby Tsani Ahwadi, Yunyun Yudiana, Nurlan Kusmaedi, "Hubungan Koordinasi Mata dan Tangan dengan Hasil Tangkapan Bola Lambung Infield, Outfield Pada Cabang Olahraga Softball”, Jurnal Terapan Ilmu Keoalhragaan Vol.01 N0.02 Tahun 2016. 
Nordin, Margareta dan Frankel, Basic Biomechanics of the Musculoskeletal System (Philadelphia: Lippincott and Wilkins: 2012).

Rihatno Taufik. "Efektifitas Pembelajaran Menggunakan Media Video dan Media Cermin Terhadap Hasil Belajar Memukul Softball”, Jurnal Pendidikan Olah Raga, Vol.3 No.1 Tahun 2014.

Ridho, dkk, "Pengaruh Latihan Horizontal Swing Terhadap Hasil Pukulan Pada
Atlet Pelatda Softball Putri Riau", "Jurnal Pendidikan Kepelatihan Olahraga UNRI, Vol.1 2013.

Rod Cross, Physics of Baseball \& Softball (New York: Springer, 2011).

Tangkudung, James dan Wahyuningtyas Puspitorini, Kepelatihan Olahraga. Jakarta: Cerdas Jaya. 2012.

Widiastuti, Belajar Keterampilan Gerak, Jakarta: FIK Universitas Negeri Jakarta, 2014 